\title{
TANK REMOTE REPAIR SYSTEM CONCEPTUAL DESIGN (U)
}

E. M. Kriikku

September 24, 2002

Westinghouse Savannah River Company LLC

Savannah River Site

Aiken, South Carolina 29802 
This document was prepared in conjunction with work accomplished under Contract No. DE-AC09-96SR18500 with the U. S. Department of Energy.

\section{DISCLAIMER}

This report was prepared as an account of work sponsored by an agency of the United States Government. Neither the United States Government nor any agency thereof, nor any of their employees, makes any warranty, express or implied, or assumes any legal liability or responsibility for the accuracy, completeness, or usefulness of any information, apparatus, product or process disclosed, or represents that its use would not infringe privately owned rights. Reference herein to any specific commercial product, process or service by trade name, trademark, manufacturer, or otherwise does not necessarily constitute or imply its endorsement, recommendation, or favoring by the United States Government or any agency thereof. The views and opinions of authors expressed herein do not necessarily state or reflect those of the United States Government or any agency thereof.

This report has been reproduced directly from the best available copy.

Available for sale to the public, in paper, from: U.S. Department of Commerce, National Technical Information Service, 5285 Port Royal Road, Springfield, VA 22161, phone: (800) 553-6847, fax: (703) 605-6900

email: orders@ntis.fedworld.gov

online ordering: http://www.ntis.gov/help/index.asp

Available electronically at http://www.osti.gov/bridge

Available for a processing fee to U.S. Department of Energy and its contractors, in paper, from: U.S. Department of Energy, Office of Scientific and Technical Information, P.O. Box 62, Oak Ridge, TN 37831-0062,

phone: (865)576-8401,

fax: (865)576-5728

email: $\underline{\text { reports@ adonis.osti.gov }}$ 
Tank Remote Repair System

WSRC-TR-2002-0041

Conceptual Design (U)

Revision

APPROVALS
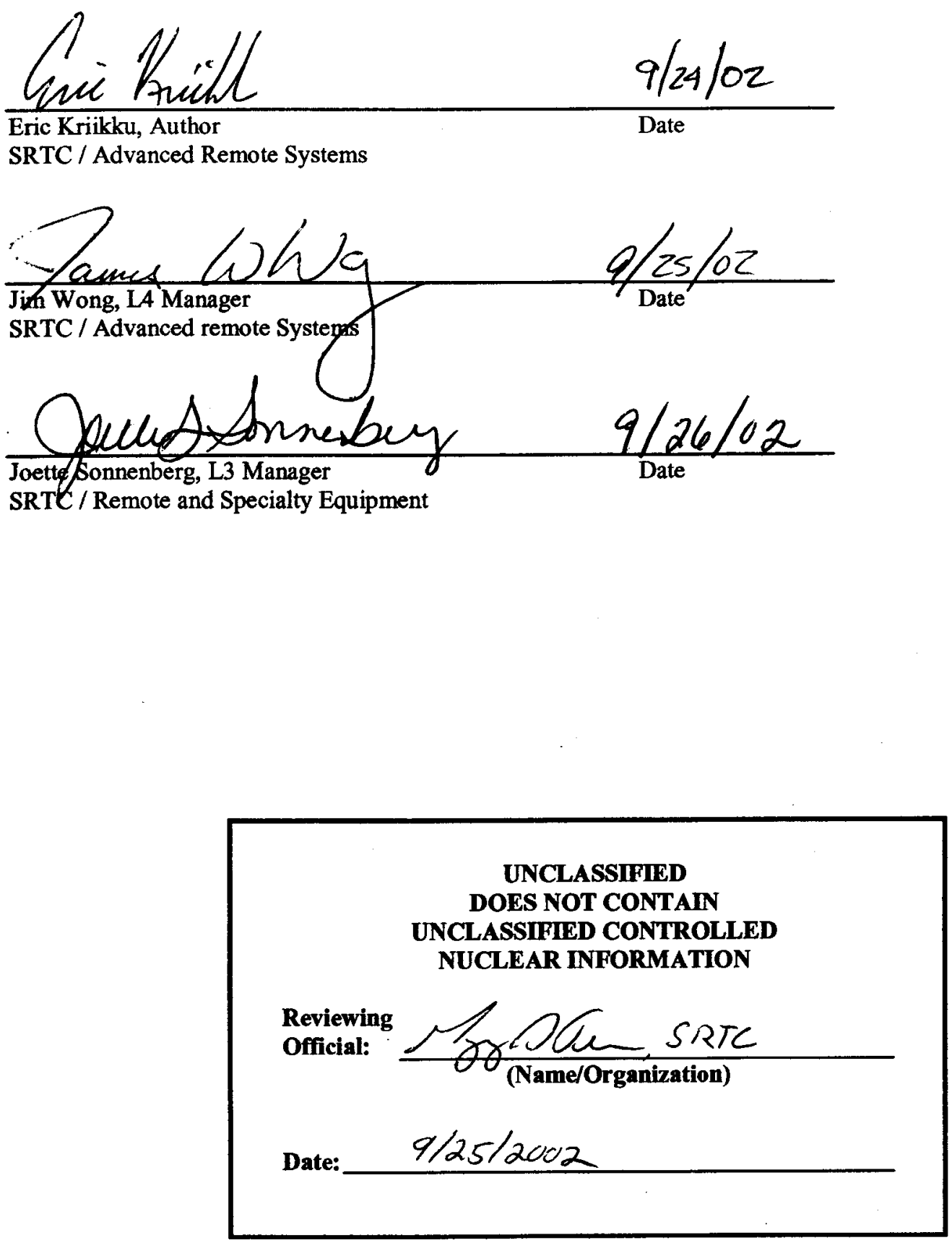


\section{TABLE OF CONTENTS}

EXECUTIVE SUMMARY
BACKGROUND
ASSUMPTIONS.
CONCEPTUAL DESIGNS
Epoxy Patch Concept
Magnetic Patch Concept
MILESTONES
CONCLUSION
REFERENCES
APPENDIX 1 - Type I Tank Details
APPENDIX 2 - Type II Tank Details.
APPENDIX 3 - Type III Tank Details
APPENDIX 4 - Type IIIA Tank Details

\section{LIST OF FIGURES}

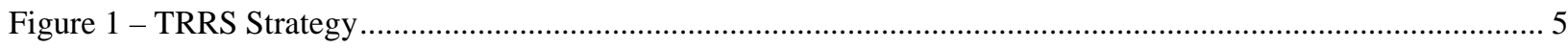

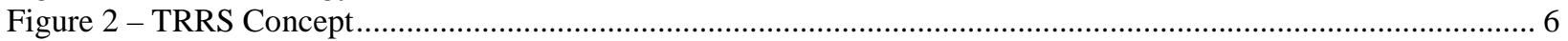

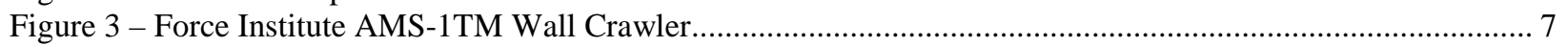

Figure 4 - Epoxy Patch Cross Section........................................................................................................ 7

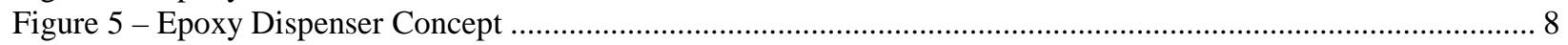

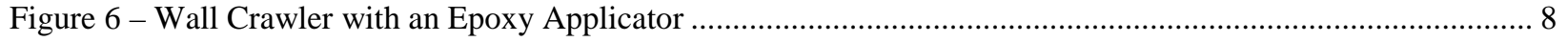

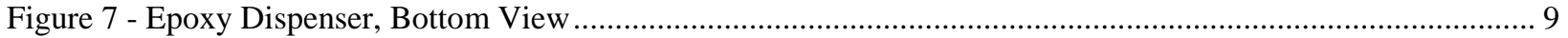

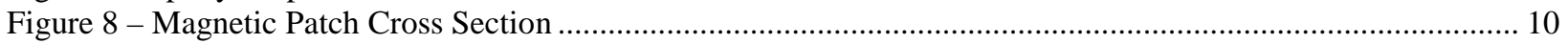

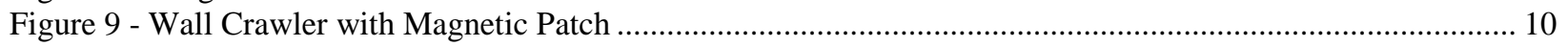

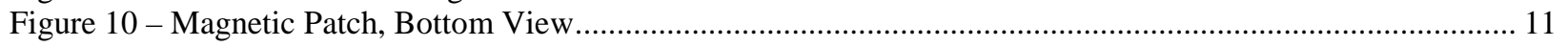

Figure 11 - Tank Mock-up: Layout (left) and Risers (right) ……....................................................................... 12

Figure 12 - Tank Mock-up: Upper Wall (left) and Lower Wall, Knuckle, and Tank Bottom (right)....................... 12

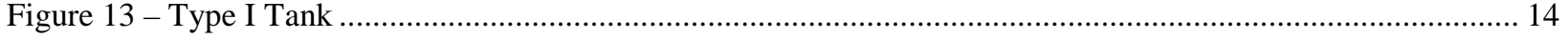

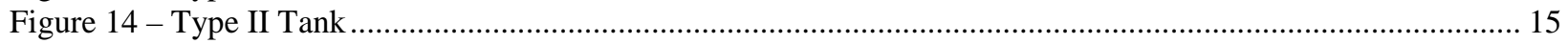

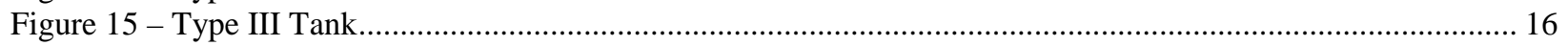

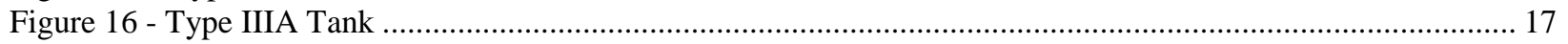




\section{EXECUTIVE SUMMARY}

This document describes two conceptual designs for a Tank Remote Repair System (TRRS) to perform leak site repairs of double shell waste tank walls (Types I, II, III, and IIIA) from the annulus space. The first concept uses a magnetic wall crawler and an epoxy patch system and the second concept uses a magnetic wall crawler and a magnetic patch system. The recommended concept uses the magnetic patch system, since it is simpler to deliver, easier to apply, and has a higher probability of stopping an active leak.

\section{BACKGROUND}

The Savannah River Site (SRS) and Hanford have tanks and transfer systems that have exceeded their original design life, but may be used for waste processing for another 30-40 years. At SRS, the wastes from recovery of plutonium and uranium are stored in large, near-surface carbon steel tanks with multiple containment barriers to prevent leakage into the surrounding environment. The oldest tanks (ca. 1955) were constructed of carbon steel and most tanks are Double Shell Tanks (DST Type I,II,III) with an annulus space between the primary carbon steel tank wall and a concrete outer shell. In the past, leak sites have been detected in the primary vessel walls in some of the Type I and Type II tanks. At the present time there are no plans to build new tanks, therefore a process to repair leaks may be useful during waste removal from the tanks. However, due to various obstructions in the annulus space of the tanks there is no assurance that all leaks can be repaired. The repair task is further complicated by the limited size (5" diameter) and number of access risers on some SRS tanks.

The waste tank repair program is co-funded by the department of Energy (DOE) Office of Science and Technology (OST) and SRS HLW division. The OST will fund and manage the waste tank repair program with the Tanks Focus Area's (TFA) Task Technical Plan (TTP) SR18WT21 and TTP SR10C131. The Savannah River Technology Center (SRTC) Materials Technology Section (MTS) is responsible for developing a tank Leak Mitigation System (LMS) under TTP SR18WT21 and the SRTC Engineered Equipment \& Systems (EES) department is responsible for integrating a delivery vehicle and the LMS under TTP SR10C131.

The TRRS Program Plan ${ }^{1}$ outlines the entire program from development to deployment. The TRRS Development \& Acquisition Strategy ${ }^{2}$ outlines funding and general scope for each fiscal year. The LMS and Vehicle Functions and Requirements ${ }^{3,4}$ include the detailed functions and requirements for each system. The LMS Material Selection Program Plan ${ }^{5}$ outlines the LMS Evaluation work to be preformed. The LMS evaluation tests are in progress, and the LMS recommendation will follow soon. The TRRS strategy is shown in Figure 1, and this report is the first stage to the TRRS design and is an FY02 deliverable. Currently the task is not funded beyond FY02.

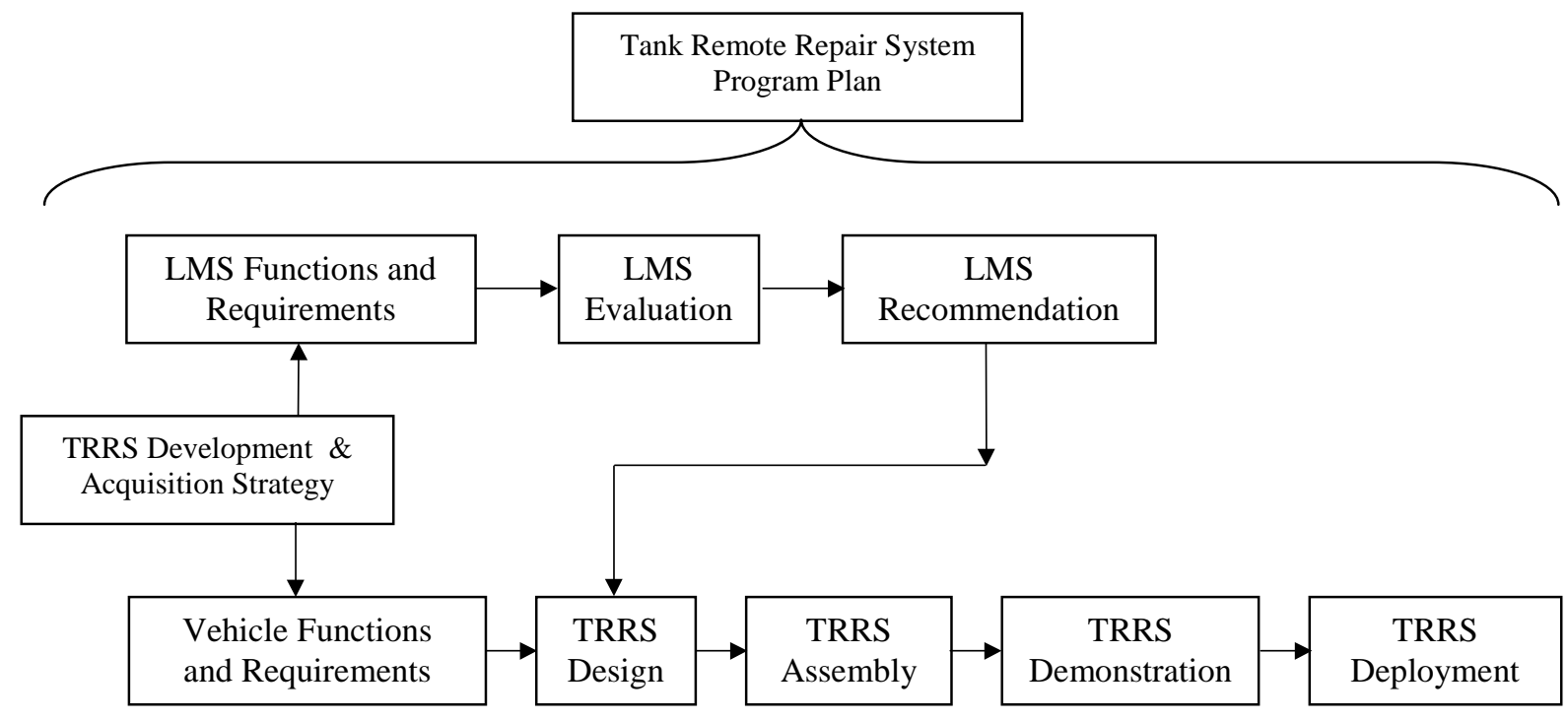

Figure 1 - TRRS Strategy 


\section{ASSUMPTIONS}

The following assumptions are made to complete the TRRS conceptual design report.

- $\quad$ SRS currently uses magnetic wall crawlers in the waste tank annulus space for visual and ultrasonic tank wall inspections. Due to the success of these magnetic wall crawlers, a similar crawler will be used as the TRRS vehicle. SRS is currently using the Force Institute AMS-1TM wall crawler.

- The leak sites needing repair are accessible via the annulus space between the primary waste tank and the secondary containment.

- The annulus space is accessible via 5.0 inch (or greater) inner diameter risers.

- The TRRS will only repair leaks on the exterior primary tank wall, not the knuckle or tank bottom.

- The TRRS will traverse weld beads and other wall imperfections (i.e. weld and concrete splatter) that are not greater than 0.5 inches high.

- Obstructions in the tank annulus (ventilation ducts, pipes, etc.) may make some tank wall areas inaccessible to the TRRS.

\section{CONCEPTUAL DESIGNS}

Figure 2 shows the overall concept for the TRRS. The vehicle, cameras, lights, and patch system will be controlled by a mobile cabinet located on the tank top. A long tether will connect the vehicle to the control cabinet. The vehicle will be deployed in the annulus space between the primary tank wall and the secondary containment on the primary tank wall exterior. The appendix includes details about Type I, II, III, IIIA tanks. This is the basic configuration currently used in SRS tank wall inspections, and has a proven record of success.

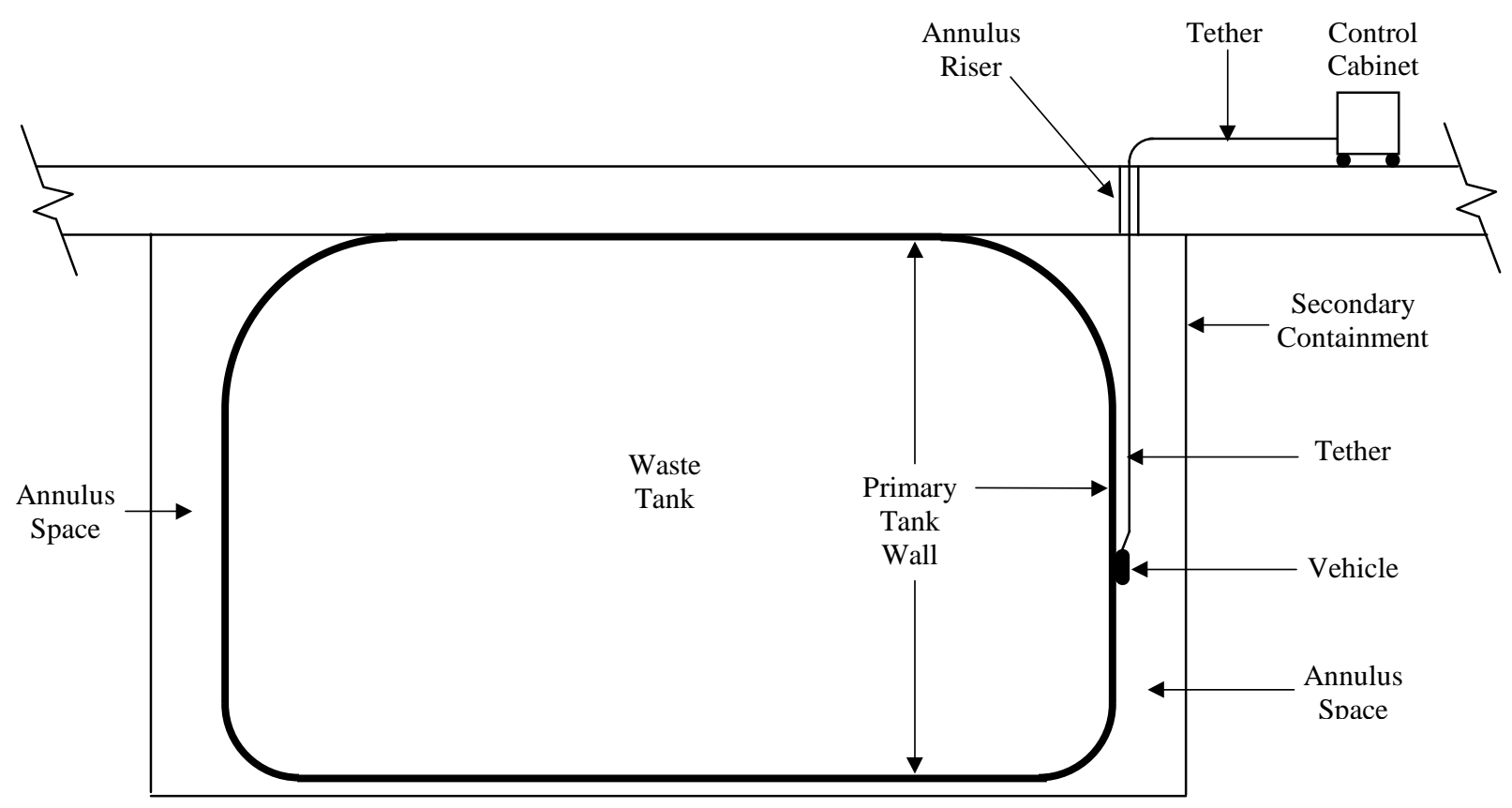

Figure 2 - TRRS Concept

Figure 3 shows a typical magnetic wall crawler, the Force Institute AMS-1TM, the pneumatic control unit, PCU-7 an the power supply, MDU-13. The TRRS concept is based on this magnetic wall crawler due to the past successful use at SRS for tank annulus visual and UT inspections. 


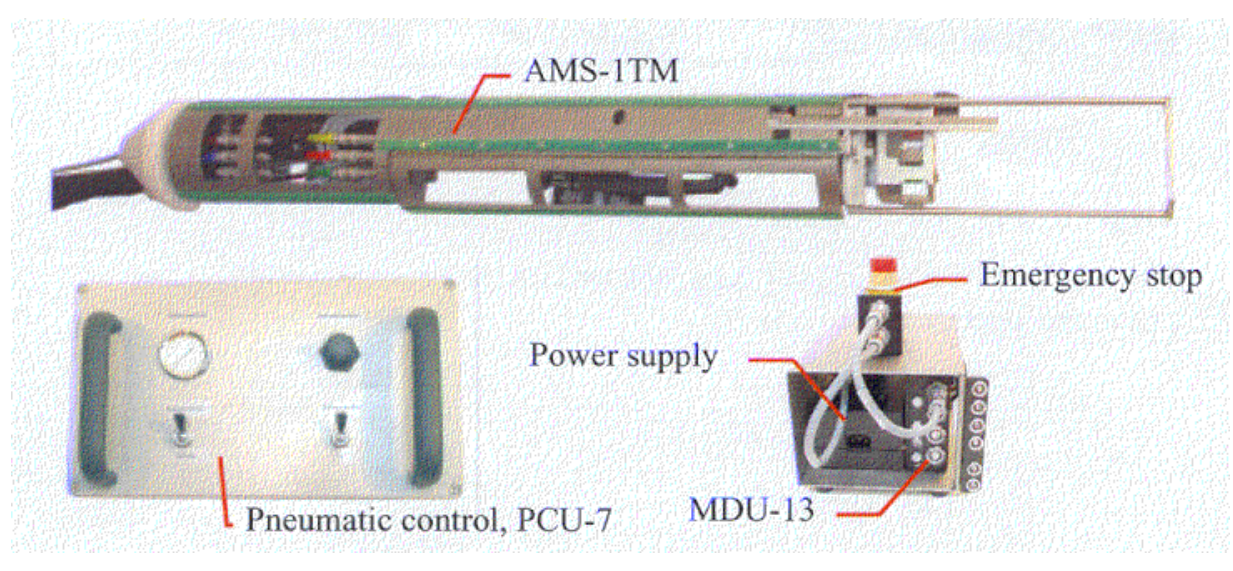

Figure 3 - Force Institute AMS-1TM Wall Crawler

The LMS evaluation work looked at several tank repair options and determined two feasible concepts. The first concept is an epoxy based patch and the second is magnetic based patch. The following sections describe these concepts, how they would be integrated with a magnetic wall crawler to make the TRRS, and the advantages and disadvantages for each.

\section{Epoxy Patch Concept}

The LMS evaluation includes testing several epoxies under various conditions, but the delivery and application details are similar for all epoxies. The two epoxy parts need to be mixed shortly before the epoxy is applied to the tank wall. The individual parts must be relatively thick so the mixed compound will adhere to the vertical tank wall during the epoxy curing time. The crawler will carry the epoxy parts to the leak site, mix the parts, and apply the epoxy to the tank wall over the crack and surrounding area. The applicator/mixer will be similar to the "double syringe" dispenser used by some commercial epoxies. The two epoxy parts are stored in separate syringe tubes that share plunger handles and outlet tip. The mixing occurs in the outlet tip. The epoxy will form a water-tight seal around the crack. Figure 4 shows a conceptual epoxy patch cross section.

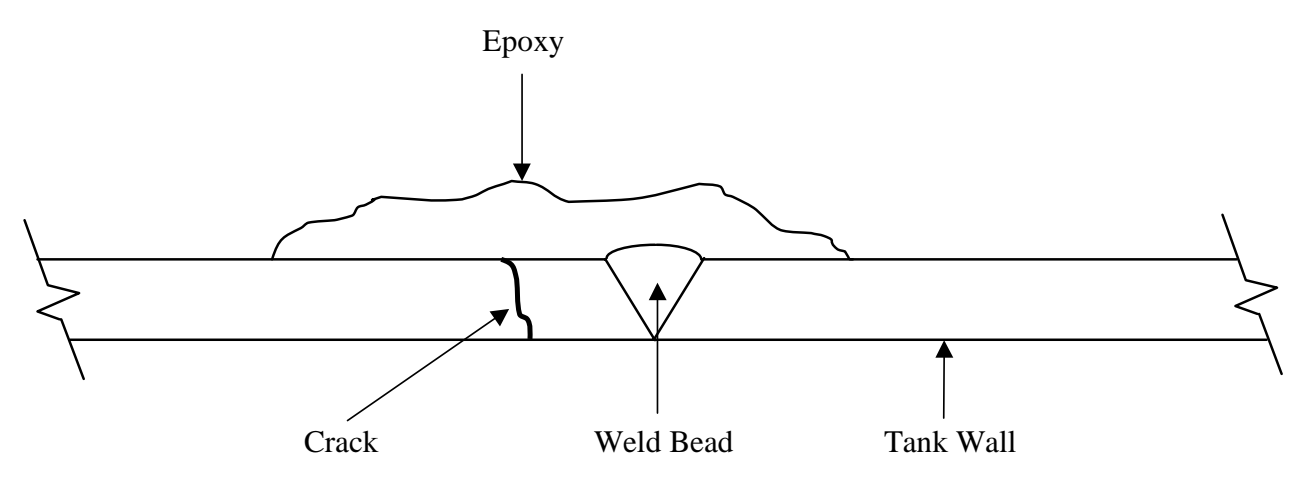

Figure 4 - Epoxy Patch Cross Section

After testing several epoxies, MTS determined that pumping the mixed, or unmixed, epoxy through long small diameter tubing is impractical due to the materials high viscosity. The only practical solution is to carry the two epoxy parts on-board the wall crawler and mix them at the leak site. Figure 5 shows the epoxy "double syringe" dispenser concept. 


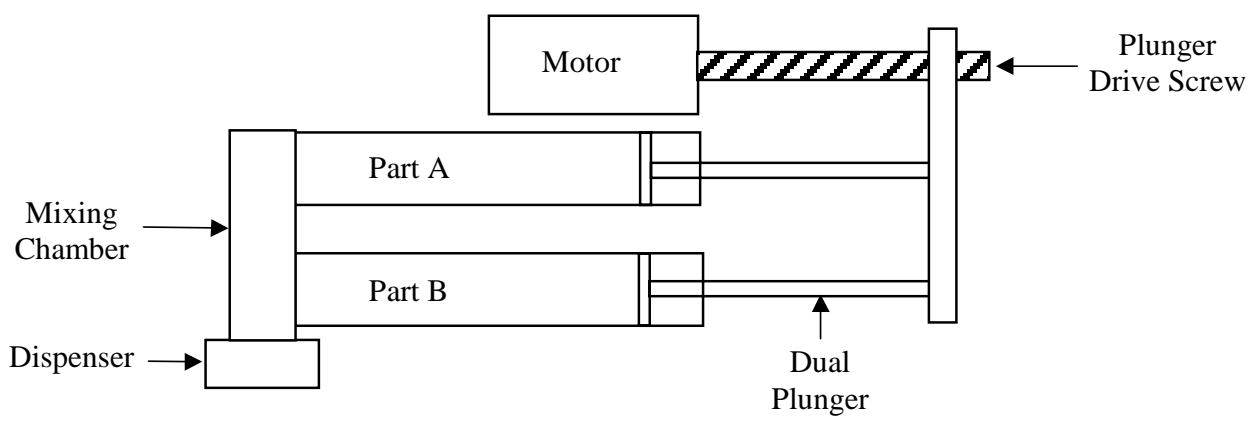

Figure 5 - Epoxy Dispenser Concept

Figure 6 shows the Force Institute magnetic wall crawler with an epoxy dispenser. The crawler is 41.73 inches long, 4.75 inches in diameter, and is drawn to scale. The epoxy dispenser is located in the area usually used for ultrasonic sensors. The epoxy dispenser was designed to fit in this existing space, so the commercial crawler would not require significant changes.

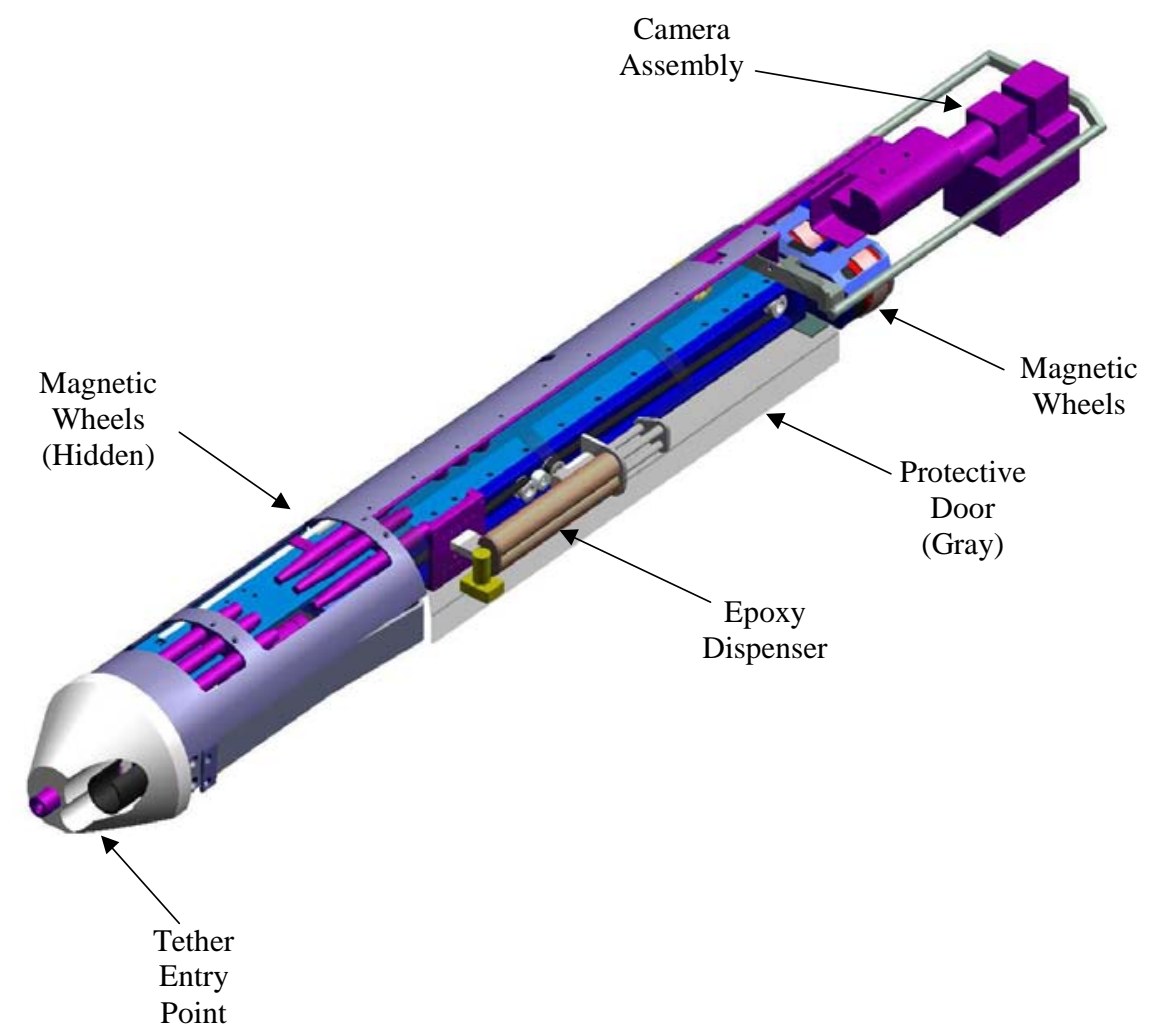

Figure 6 - Wall Crawler with an Epoxy Applicator 
Figure 7 shows a close-up bottom view of the epoxy dispenser. The epoxy dispenser can be moved back and forth in the crawler cargo area with the device that normally moves the ultrasonic sensors. If a larger quantity of epoxy is required, this functionality could be removed and larger epoxy tubes could be used.

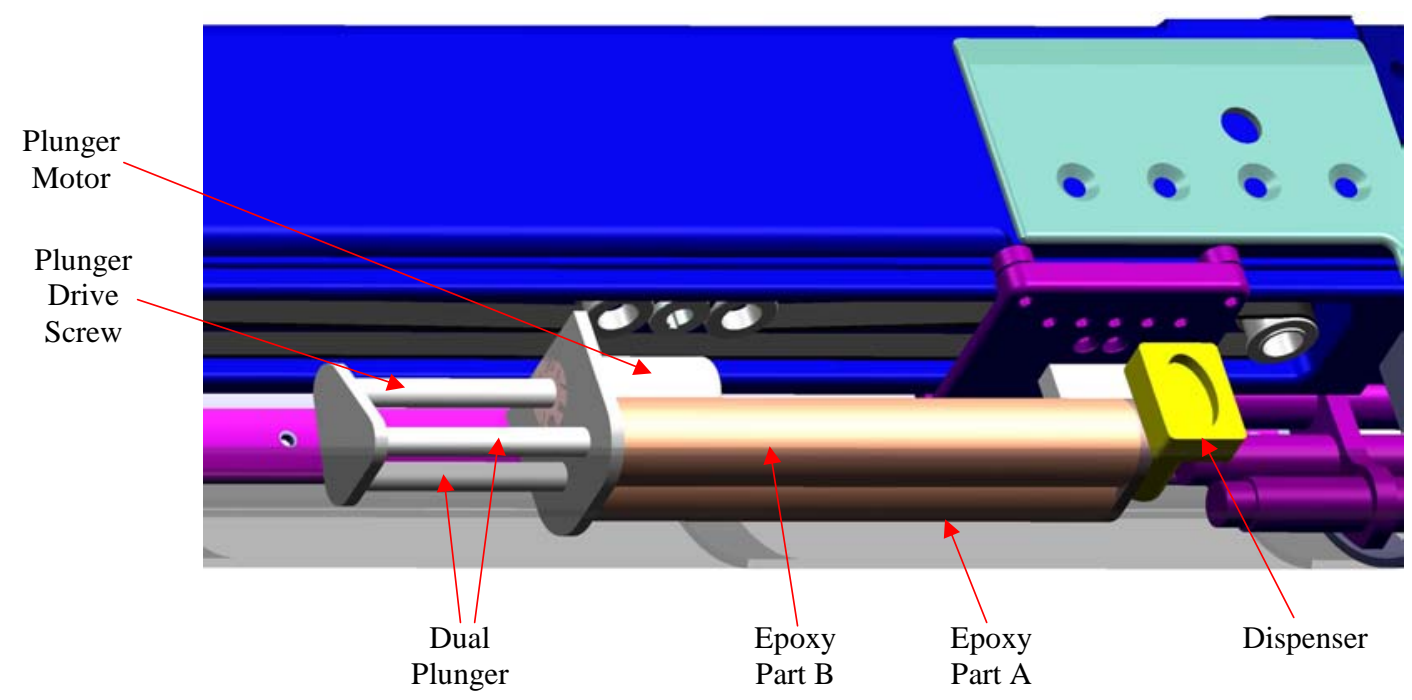

Figure 7 - Epoxy Dispenser, Bottom View

The following are advantages to the epoxy concept are:

- Testing showed the epoxies should work under the assumed conditions.

- Future tank wall analysis (UT testing) can be done through the epoxy material.

The following are disadvantages to the epoxy concept:

- Remotely mixing and dispensing epoxy in the tank annulus is untested and risky.

- Applying epoxy in the tank annulus is untested and risky.

- The limited supply of epoxy onboard limits the number of cracks that can be sealed per deployment.

- Examining the tank wall through the epoxy material is untested.

- There is a low probability the system will work on active leak sites.

\section{Magnetic Patch Concept}

The LMS evaluation includes testing a novel magnetic patch concept. The crawler will carry the magnetic patch with small deployment arm. The vehicle will maneuver the patch above the leak site and the arm will be actuated to place the patch over the crack. The patch rare earth magnets pull the backing plate towards the tank wall. The backing plate compresses the seal material against the crack and surrounding tank wall. The seal material will form a water-tight seal around the crack. Figure 8 shows the magnetic patch concept cross section. 


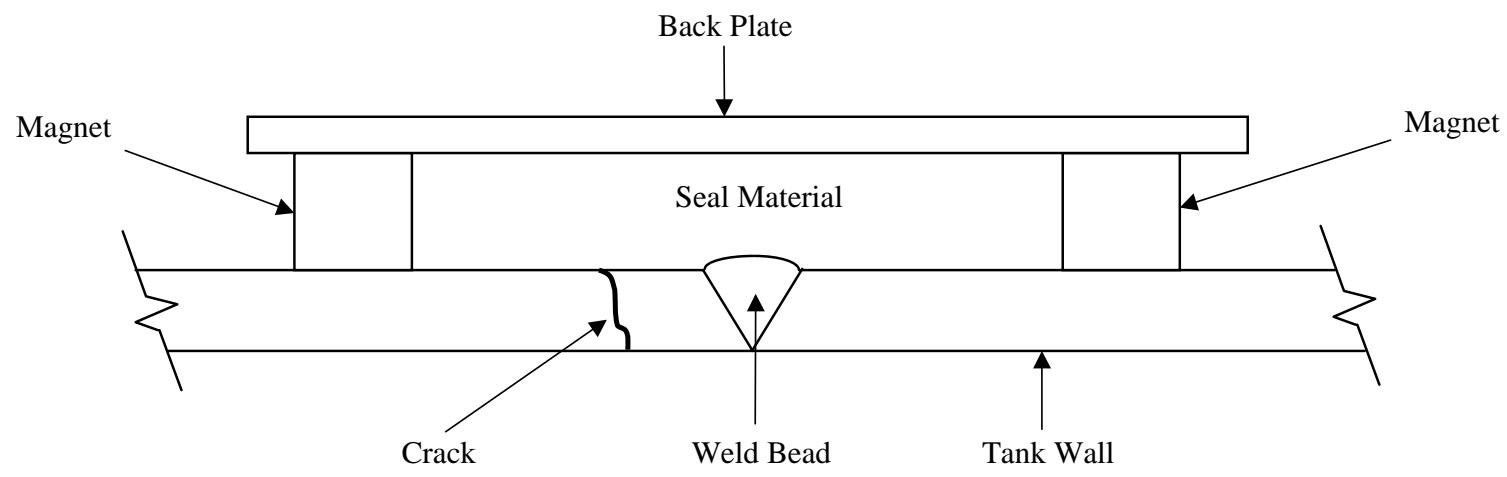

Figure 8 - Magnetic Patch Cross Section

Figure 9 shows the Force Institute magnetic wall crawler with the magnetic patch. The crawler is 41.73 inches long, 4.75 inches in diameter, and is drawn to scale. The magnetic patch is located in the area usually used for ultrasonic sensors. The magnetic patch and deployment arm were designed to fit in this existing space, so the commercial crawler would not require significant changes.

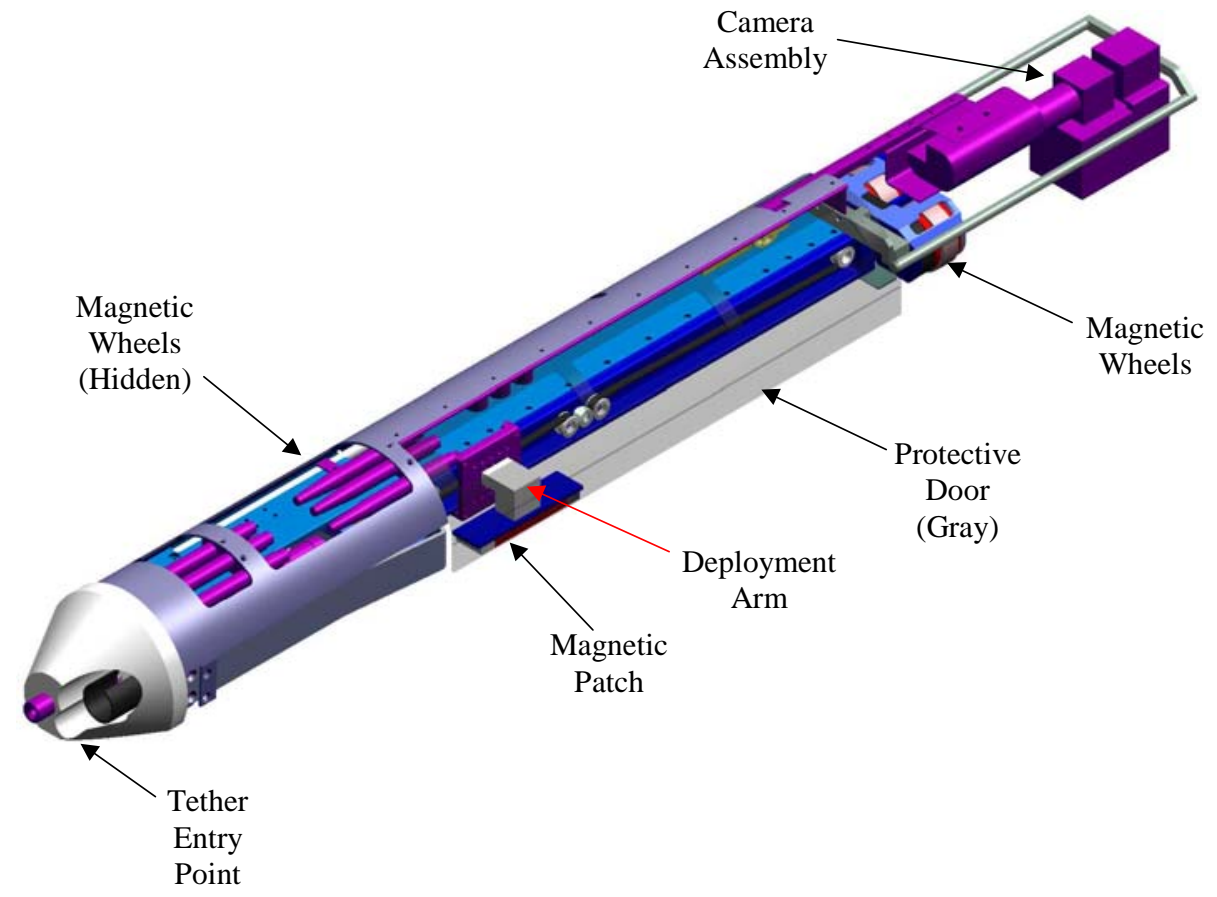

Figure 9 - Wall Crawler with Magnetic Patch

Figure 10 shows a close-up bottom view of the magnetic patch. The deployment arm, which holds the patch, can be moved back and forth in the crawler cargo area with the device that normally moves the ultrasonic sensors. The magnetic patch shown is 1 inch by 4 inches. If a larger magnetic patch is required, this functionality could be removed and a larger patch could be used. 


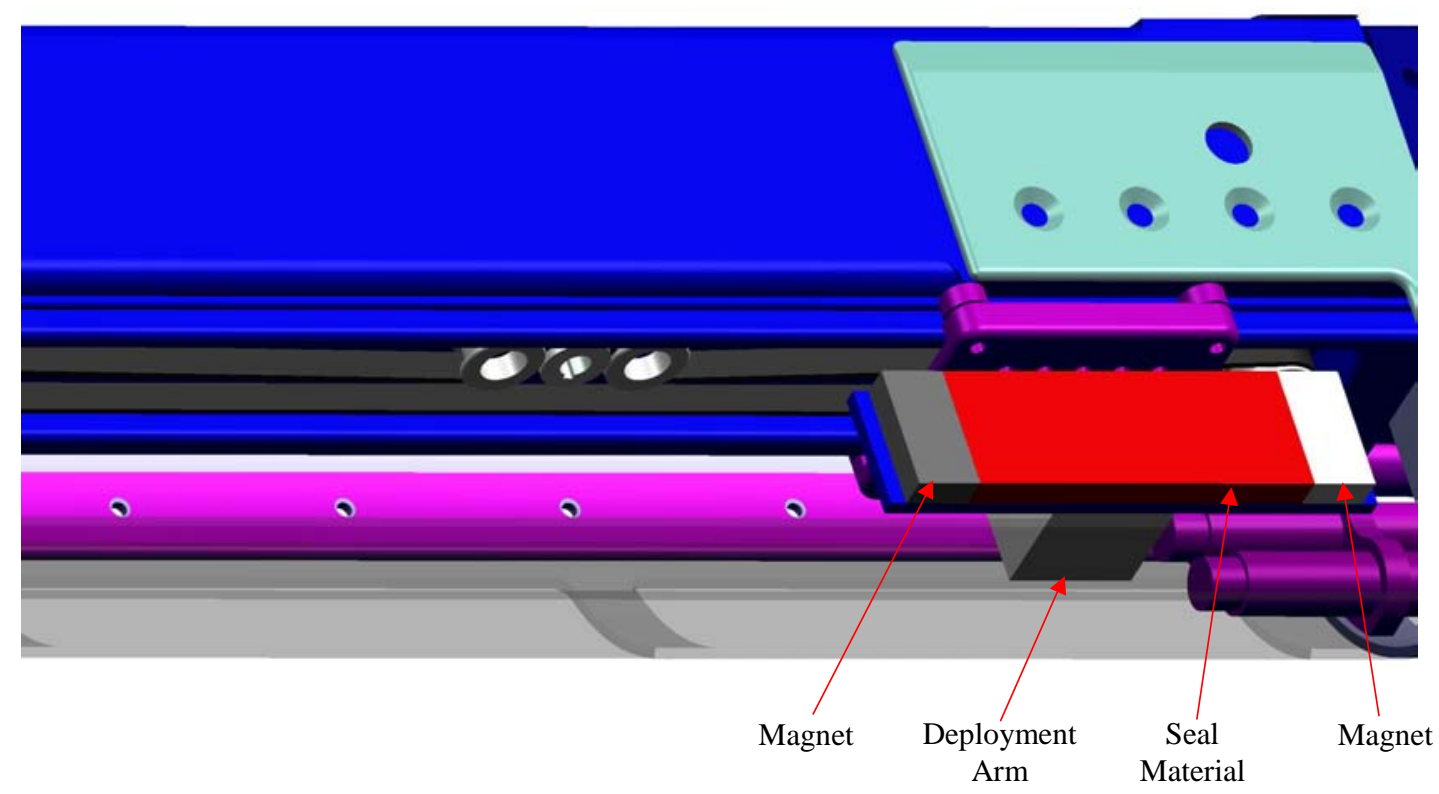

Figure 10 - Magnetic Patch, Bottom View

The following are advantages to the magnetic patch concept:

- Testing showed that the magnetic patches should work under the assumed conditions.

- Applying the patch is relatively simple.

- The patch can be removed to examine the tank wall.

- There is a high probability the system will work on active leak sites.

The following are disadvantages to the magnetic patch concept:

- The patch dimensions will limit the area that can be sealed. Patches placed next to each other may allow for larger areas to be sealed, but this needs to be tested.

\section{MILESTONES}

The TRRS vehicle work is funded by TTP SR10C131 and the Tank Remote Repair System task has two milestones in FY02. The first milestone is entitled, "Complete the Large Scale Vehicle Test Platform", or Tank Mock-up, and is milestone number 175-3.2-1. SRTC designed the large scale vehicle test platform to include a 5 inch diameter riser, several wall section of various thickness, a lower tank wall knuckle, a tank bottom section, and removable plates in the wall, knuckle, and bottom. SRTC hired a sub-contractor to fabricate and install it in SRS bldg. 723-A. Figures 11 and 12 show the Tank Mock-up layout and the completed large scale vehicle test platform. 

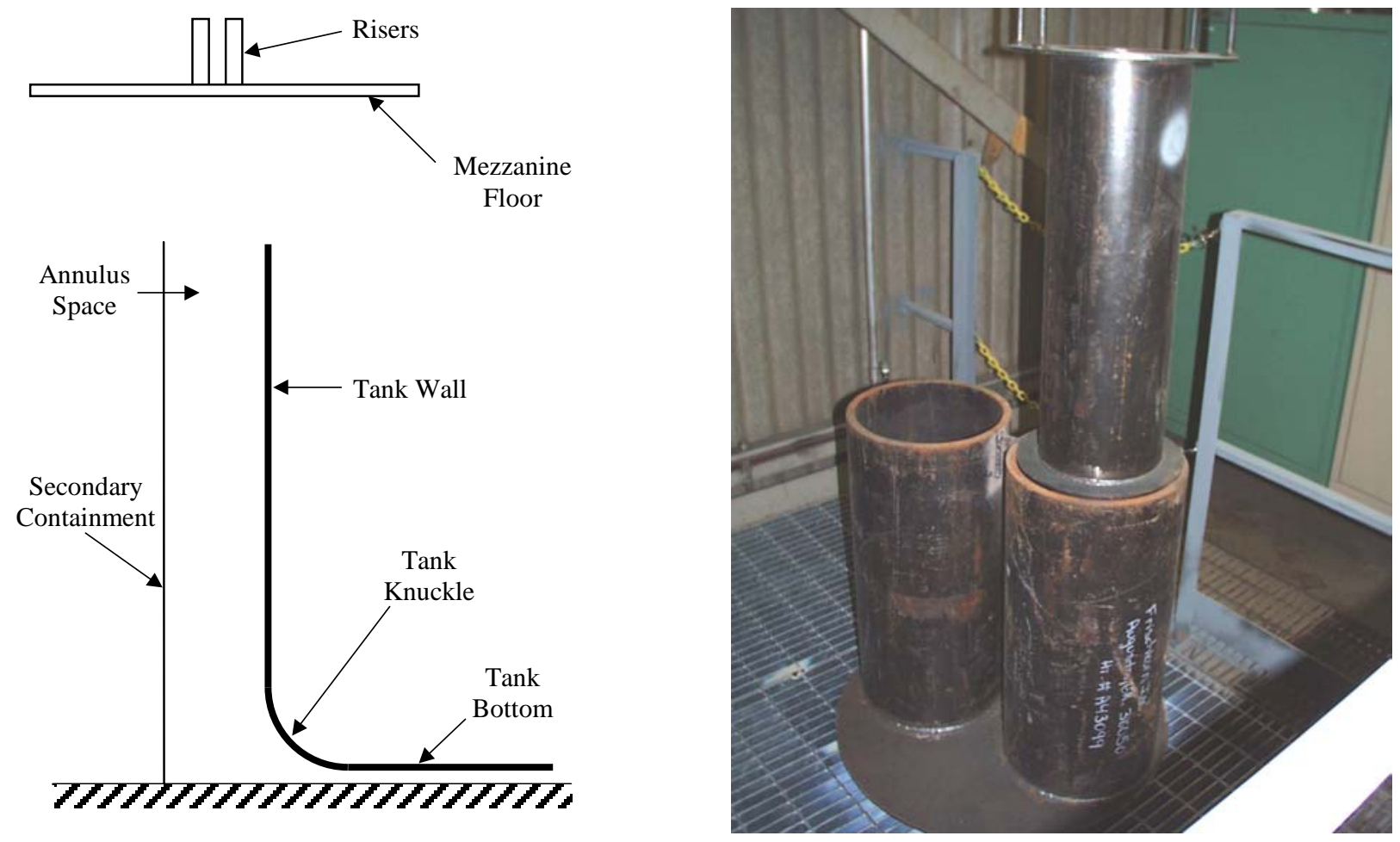

Figure 11 - Tank Mock-up: Layout (left) and Risers (right)
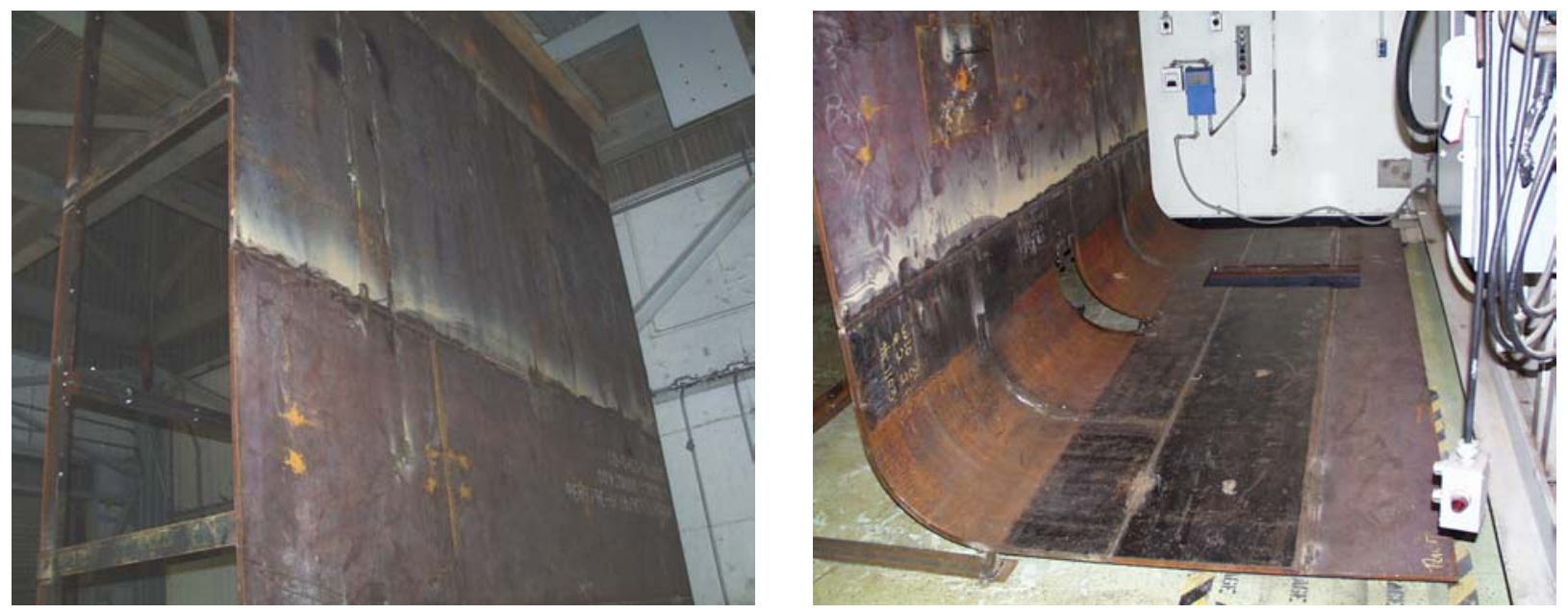

Figure 12 - Tank Mock-up: Upper Wall (left) and Lower Wall, Knuckle, and Tank Bottom (right)

The second milestone is entitled, "Issue TRRS Conceptual Design" and is milestone number 175-3.2-2. This report documents the TRRS conceptual design. 


\section{CONCLUSION}

This report discusses two TRRS concepts. The first concept uses a magnetic wheeled wall crawler to deliver an epoxy patch and the second concept uses a magnetic wheeled wall crawler to deliver a magnetic patch. The report includes advantages and disadvantages for each concept. The magnetic patch concept is the recommended due to the easier application in the tank annulus space, positive preliminary test results, and high probability of stopping active leak sites. The magnetic patch concept is being tested in the laboratory this fiscal year. If the test results are positive, the TRRS system should be thoroughly evaluated in a test environment and deployed as needed.

\section{REFERENCES}

1. Wiersma, B. J., Program Plan: Development, Delivery, and Deployment of Repair Options for SRS High Level Waste Tanks (U), WSRC-TR-2001-00469, Savannah River Site, Aiken, SC 29808 (11/2001).

2. Kriikku, E. M., Development and Acquisition Strategy for the Tank Remote Repair System (U). WSRC-TR2001-00271, Savannah River Site, Aiken, SC 29808 (9/7/2001).

3. Subramanian, K. H., Wiersma, B. J., Functions and Requirements for the Leak Mitigation System of the Savannah River Site Double Shell High Level Waste Tanks, WSRC-TR-2001-00438, Savannah River Site, Aiken, SC 29808 (9/2001).

4. Kriikku, E. M., Functions and Requirements for the Tank Remote Repair System (U). WSRC-TR-2001-00272, Savannah River Site, Aiken, SC 29808 (9/5/2001).

5. Subramanian, K. H., Leak Mitigation System Materials Selection Program Plan, WSRC-TR-2002-00066, Savannah River Site, Aiken, SC 29808 (2/2002). 


\section{APPENDIX 1 - Type I Tank Details}

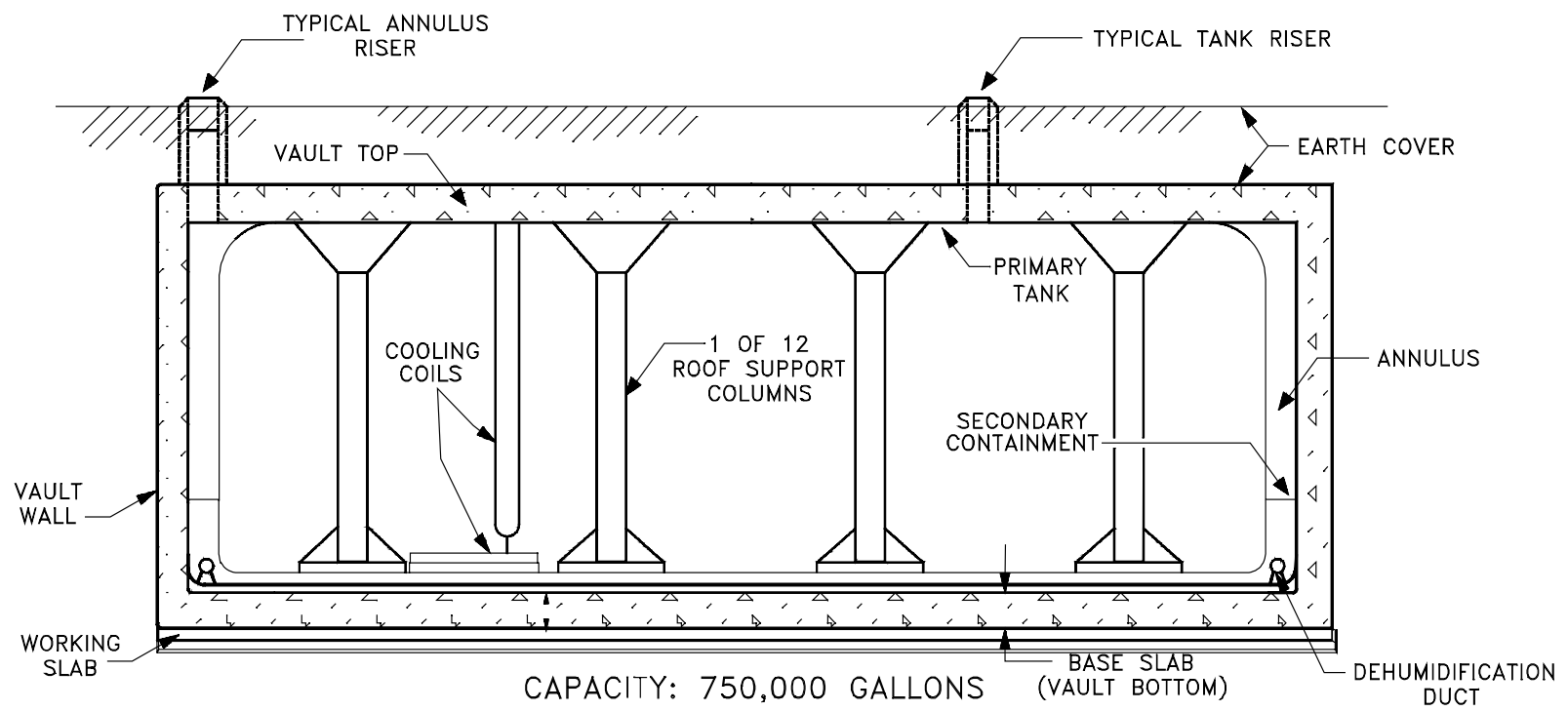

WI124004

$07 \quad 08 \quad 94$

Figure 13 - Type I Tank

Waste Tank Capacity

Primary Tank Shell

Design Temperature

Design Pressure

Cooling

Secondary Containment

Roof Support

Concrete Vault

Radiation Shielding

Location
750,000 gallons

Closed top construction - 75 foot D x 24.5 foot $\mathrm{H}$.

Constructed of carbon steel, $1 / 2$ inch thick throughout

$220^{\circ} \mathrm{F} \max$

1.4 psi max

36 parallel coils supported by the roof with 2 horizontal coils across the tank bottom

Steel pan -80 foot D x 5 foot H. Constructed of carbon steel, $1 / 2$ inch thick throughout.

Twelve 2 foot OD, $1 / 2$ inch thick carbon steel columns filled with concrete.

Columns are supported by the tank bottom.

22-inch thick wall and roof. 30-inch thick floor. Waterproofed on outside of wall, top of roof, and under foundation.

9-foot thick layer of earth on top of roof.

Tanks 1 through 8 are in F Area and Tanks 9 through 12 are in H Area. 


\section{APPENDIX 2 - Type II Tank Details}

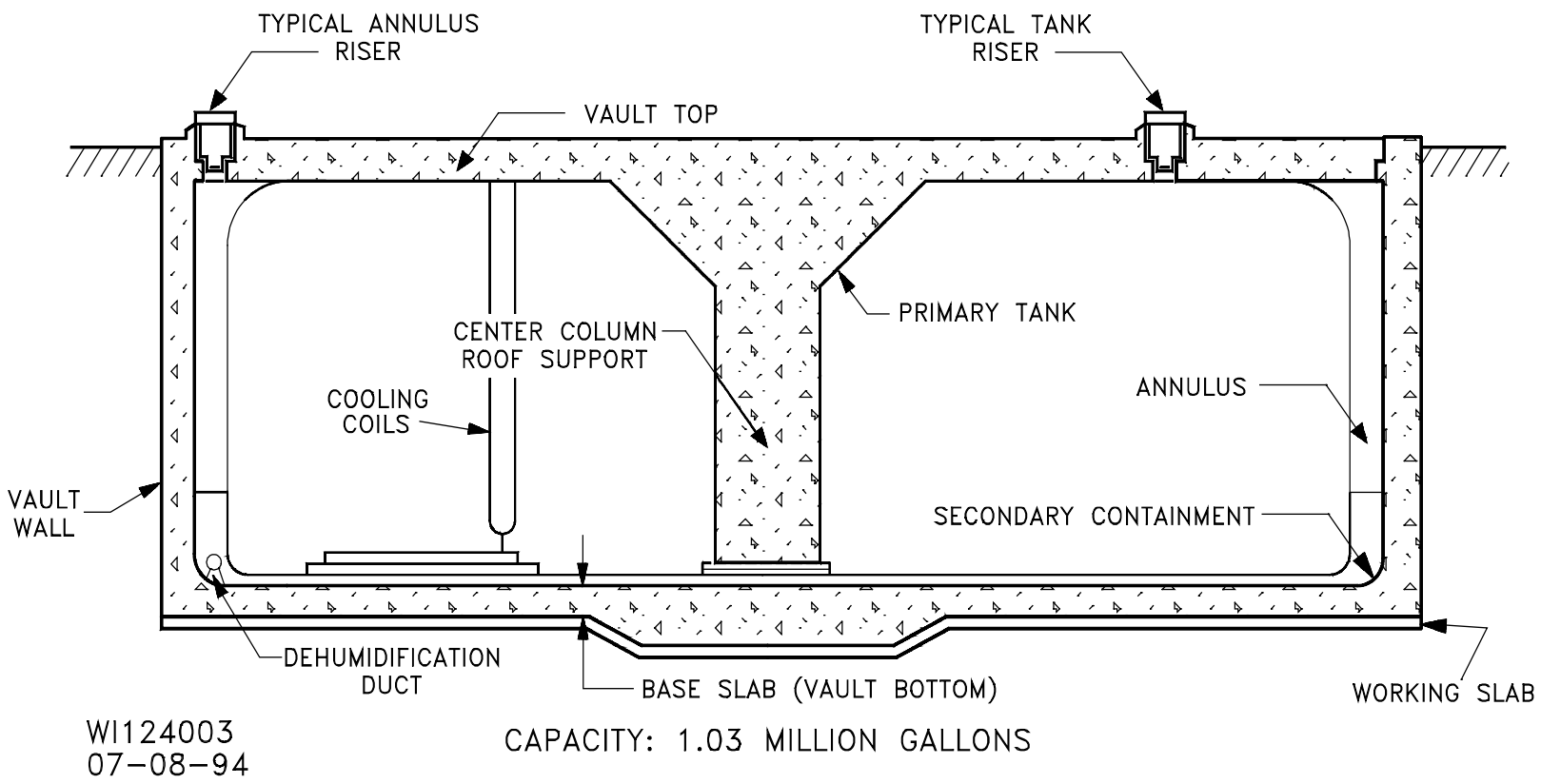

Figure 14 - Type II Tank

Waste Tank Capacity

Primary Tank Shell

Design Temperature

Design Pressure

Cooling

Secondary Containment

Roof Support

Concrete Vault

Radiation Shielding

Location
1,030,000 gallons

Closed top construction - 85 foot $\mathrm{D} \times 27$ foot $\mathrm{H}$.

Constructed of carbon steel. Thicknesses: top/bottom $-1 / 2$ inch; upper knuckle plate - 9/16 inch; wall - 5/8 inch; lower knuckle plate $-7 / 8$ inch.

$350^{\circ} \mathrm{F} \max$

2.0 psi max

44 parallel coils supported by the roof and 4 horizontal coils across the bottom.

Saucer Construction - 90 foot D x 5 foot H. Constructed of carbon steel, $1 / 2$ inch thick throughout.

Once central concrete column clad with $1 / 2$ inch carbon steel.

33-inch thick wall, 45-inch thick roof, 42-inch thick floor.

45-inch thick concrete roof with no earth overburden.

Tanks 13 through 16 are in $\mathrm{H}$ Area. 


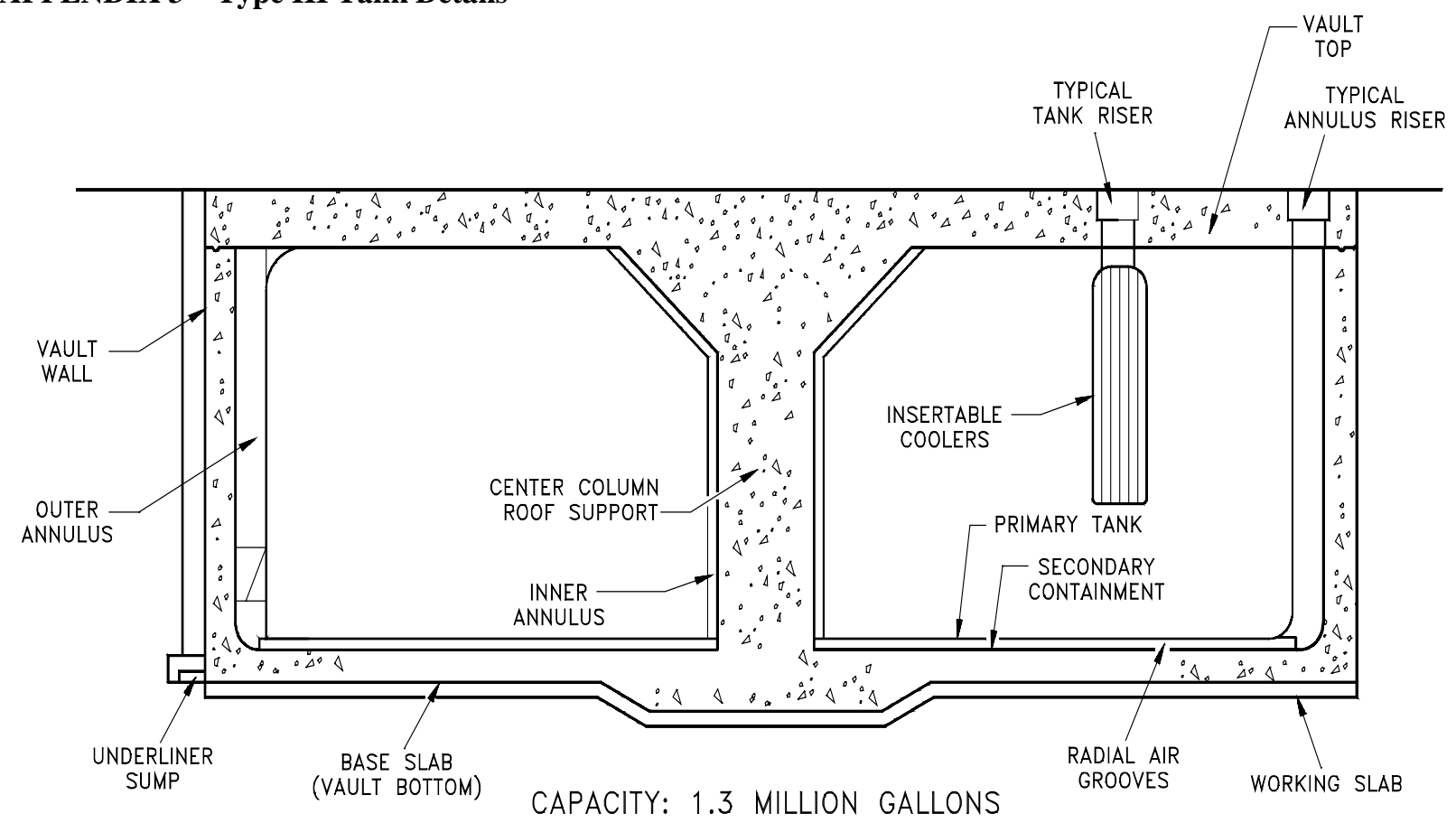

WI124049

$07-11-94$

Figure 15 - Type III Tank

Waste Tank Capacity

Primary Tank Shell

Design Pressure

Cooling

Secondary Containment

Roof Support

Concrete Vault

Radiation Shielding

Location
$1,300,000$ gallons

Closed top construction -85 foot $\mathrm{D} \times 33$ foot $\mathrm{H}$.

Constructed of carbon steel. Thicknesses: top/bottom $-1 / 2$ inch; upper knuckle plate $-3 / 4$ inch; outer wall tapers from $3 / 4$ inch at bottom to $1 / 2$ inch at top. Inner wall tapers from $5 / 8$ inch at bottom to $1 / 2$ inch at the top. Full stress relief is in place at $1100^{\circ} \mathrm{F}$.

2.2 psi max

Type III tanks have cooling coil bundles. Bottom coiling for this type is provided by forced air glow through grooved channels in the concrete beneath the tank.

Closed top construction - 90 foot $\mathrm{D}$ x 5 foot $\mathrm{H}$. Constructed of carbon steel. Once central concrete column supported on concrete foundation. 30-inch thick walls, 48-inch thick roof, 42-inch thick floor. 48-inch thick concrete roof with no earth overburden.

Tanks 33 and 34 are in F Area. Tanks 29 through 32 are in H Area. 


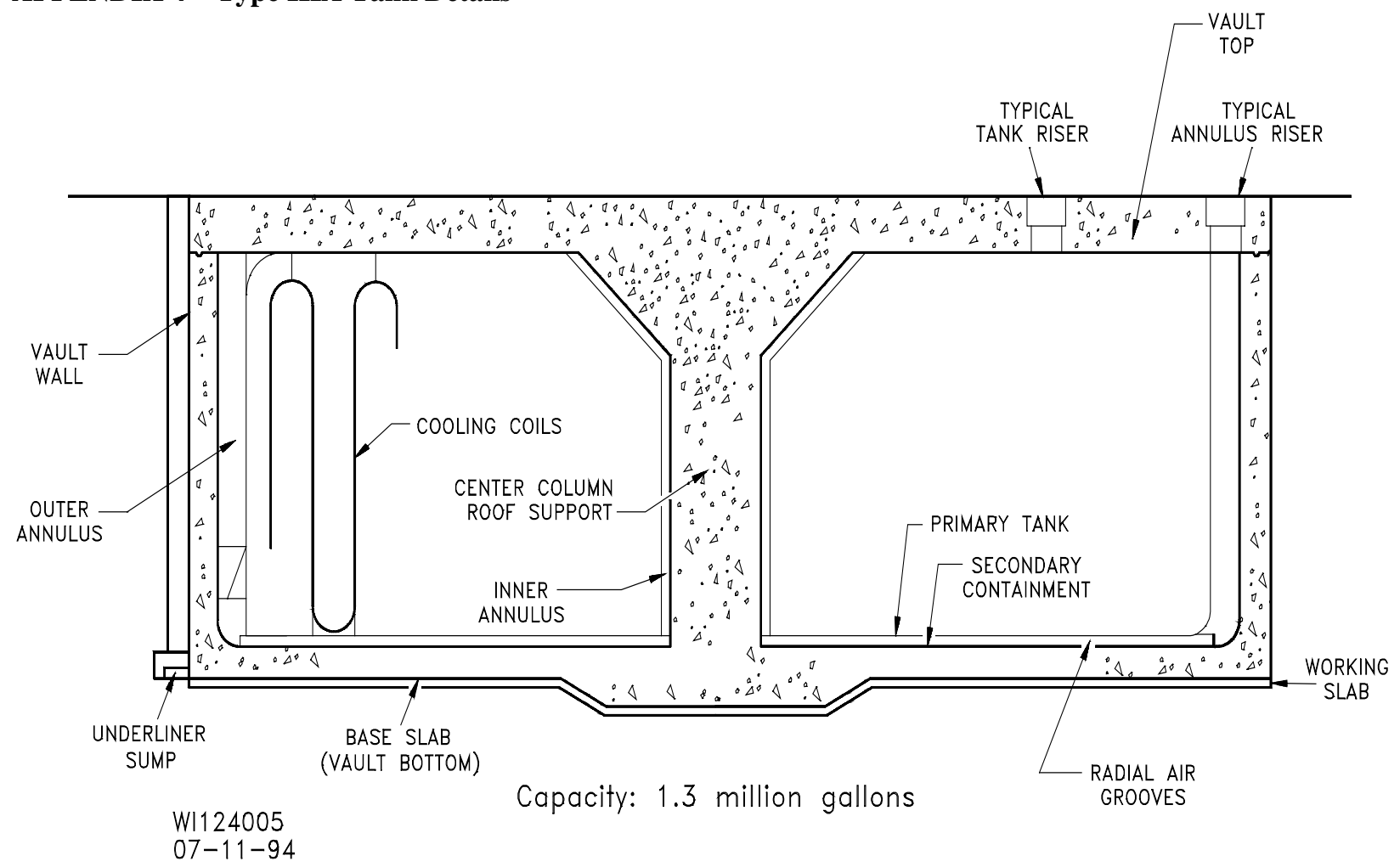

Figure 16 - Type IIIA Tank

Waste Tank Capacity Primary Tank Shell

Design Pressure Cooling

Secondary Containment Roof Support

Concrete Vault Radiation Shielding Location
$1,300,000$ gallons

Closed top construction - 85 foot D x 33 foot $\mathrm{H}$.

Constructed of carbon steel. Thicknesses: top/bottom $-1 / 2$ inch; upper knuckle plate $-3 / 4$ inch; outer wall tapers from $3 / 4$ inch at bottom to $1 / 2$ inch at top. Inner wall tapers from $5 / 8$ inch at bottom to $1 / 2$ inch at the top. Full stress relief is in place at $1100^{\circ} \mathrm{F}$.

2.2 psi max

Type III tanks have vertical cooling coils supported from the tank bottom. Bottom coiling for this type is provided by forced air glow through grooved channels in the concrete beneath the tank.

Closed top construction -90 foot $\mathrm{D}$ x 5 foot $\mathrm{H}$. Constructed of carbon steel.

Once central concrete column supported on concrete foundation. Annulus space around column.

30-inch thick walls, 48-inch thick roof, 42-inch thick floor.

48-inch thick concrete roof with no earth overburden.

Tanks 33 and 34 are in F Area. Tanks 29 through 32 are in H Area. 